\title{
Mur jako granica symboliczna. Funkcje przekształceń semantycznych we wspomnieniach o getcie warszawskim - próba refleksji
}

W publikacji Tekst wobec Zagłady. O relacjach z getta warszawskiego Jacek Leociak podkreśla, że same relacje są materiałem zróżnicowanym gatunkowo i narracyjnie, lecz zachowują ,"jedność miejsca, czasu i akcji - jak w antycznej tragedii" ${ }^{1}$. Relacje z getta warszawskiego dotyczą więc wspomnień osadzonych w ściśle określonym kontekście, zarówno historycznym, jak i geograficznym, a kluczowym zdarzeniem (czy bardziej precyzyjnie to określając grupą zdarzeń) jest Zagłada. Autor zwraca uwagę na to, że wymiar doświadczenia zapisanego $\mathrm{w}$ relacjach $\mathrm{z}$ getta jest zarówno ,jednostkowy i uniwersalny, prywatny i powszechny" ${ }^{2}$. Zapiski te więc są świadectwem nie tylko doświadczenia indywidualnego, lecz także doświadczeń zbiorowych z tamtego okresu. Oznacza to możliwość odczytywania pojedynczych relacji jako składowych całościowej opowieści o Zagładzie. W niniejszym artykule interpretować będę jedynie niewielki element machiny Zagłady - mur getta - a właściwie to, jak był postrzegany przez mieszkanki Warszawy. By dopełnić opowieść, czy raczej przyjrzeć się recepcji muru z obu jego stron,

\footnotetext{
* Poniższy artykuł jest znacznie przeredagowaną częścią mojej pracy magisterskiej obronionej w Katedrze Studiów Interkulturowych Europy Środkowo-Wschodniej w Uniwersytecie Warszawskim. Kwerendy do pracy prowadziłam w latach 2014-2015 na potrzeby projektu Archiwum Kobiet:piszące realizowanego przy Instytucie Badań Literackich Polskiej Akademii Nauk.

1 J. Leociak, Tekst wobec Zagłady. O relacjach z getta warszawskiego, Torun 2016, s. 28.

2 Tamże.
} 
poza relacjami z wnętrza getta postanowiłam włączyć do analizy świadectwa spoza zamkniętej dzielnicy żydowskiej, w których pojawia się przynajmniej wzmianka o tej szczególnej granicy. W centrum swoich dociekań lokuję pewne przekształcenia semantyczne, pojawiające się $\mathrm{w}$ dokumentach osobistych kobiet. Język relacji, jako tekst, jest więc dla mnie językiem znaczeń i ukrytych $\mathrm{w}$ nim kodów kulturowych, które staram się wyodrębnić ${ }^{3}$. Poniższy artykuł stanowi zatem próbę refleksji nad znaczeniem zastosowania pewnych konkretnych środków stylistycznych, celowości ich użycia oraz ich symbolicznego znaczenia. Podstawą analizy są fragmenty czterech niepublikowanych relacji.

W Medytacjach Pascaliańskich Pierre Bourdieu wprowadza pojęcie przemocy symbolicznej, które rozwija w kolejnych pracach, odnosząc do różnych aspektów życia społecznego, oraz analizuje sposoby, w jakie dotyka ona grup niewiększościowych. Bourdieu podkreśla fakt, że mimo iż przemoc symboliczną trudno zidentyfikować i zakwalifikować jako przemoc w ogóle, to jej efekty są absolutnie realne. Konsekwencje lokują się zarówno w sferze niewidocznej (nastrój, nastawienie, samopoczucie), jak i materialnej (inne zarobki, separacja przestrzenna bądź wykluczenie z życia społecznego) ${ }^{4}$. Przemoc symboliczną cechuje równocześnie swoista "subtelność", sprawiająca, że osoby, które jej doznają, nie identyfikują jej jako przemocy właśnie, nie rozpoznają jej opresywnego charakteru. Grupa niewiększościowa przyjmuje więc dominację jako „naturalną”.

Przemoc symboliczna istnieje więc dzięki szczególnemu typowi posłuszeństwa, którego zdominowany nie może wypowiedzieć dominującemu (i dominacji), gdyż myśląc o nim i o sobie oraz o łączących ich relacjach, dysponuje narzędziem poznawania, które jest im wspólne, a które - pośrednicząc w procesie wcielania dominacji - zarazem wprowadza tę relację jako naturalną ${ }^{5}$.

Wcielanie dominacji objawia się więc również (a nawet przede wszystkim) poprzez język - ten sam dla dominujących i zdominowanych. Przyglądając się więc językowi wspomnień i relacji o getcie warszawskim (pi-

\footnotetext{
3 Por. D. Bachmann-Medick, Cultural turns. Nowe kierunki w naukach o kulturze, przeł. K. Krzemieniowa, Warszawa 2012, s. 84-87.

4 „Ujmując «symboliczne» w opozycji do «realnego», zakładalibyśmy, że przemoc symboliczna jest pozbawioną wymiaru realności przemocą czysto «duchową». Celem materialistycznej teorii ekonomii dóbr symbolicznych [...] jest przekroczenie owego naiwnego dualizmu właściwego prymarnemu materializmowi. Chodzi więc o ukazanie obiektywnego wymiaru subiektywnego doświadczenia dominacji" [P. Bourdieu, Męska dominacja, przeł. L. Kopciewicz, Warszawa 2004, s. 46-48].

5 Tamże, s. 48.
} 
sanym zarówno z wnętrza getta, jak i spoza jego granic), zwracam uwagę na występowanie w nich pewnych środków stylistycznych i przekształceń semantycznych mogących obrazować granicę symboliczną, takich jak hiperbola, ironia, alegoria. Skupiam się na słowach, które w zestawieniu z innymi wydobywają nieuchwytne wcześniej znaczenia, ujawniające się dopiero w ściśle określonym kontekście. Za pomocą analizy znaczeniowej tychże przekształceń usiłuję zatem zrekonstruować pewne napięcia wskazujące na dominację symboliczną.

\section{Hiperbolizacja polskiego cierpienia}

Telefony $\mathrm{w}$ ghetcie nie funkcjonują, przerwano połączenie $\mathrm{z}$ nami $\mathrm{z}$ racji spraw futrzanych. Skończyły się, ale milczenie trwa nadal. Czy tak ma już być? Wykorzystano okoliczność, lub zarządzono kary. Jedynie lekarze jeszcze - co za humanitarność pozostali przy dawnych względach.

Dostałam od właściciela tutaj przepisy prawne obowiązujące w zabranej, włączonej do Reichu części Polski. Jesteśmy tam raczej bez prawa... Zrównani z żydami ${ }^{6}$.

Aurelia Wyleżyńska spisywała swoje Notatki pamiętnikarskie podczas drugiej wojny światowej. Przed wojną również była pisarką. Jej wspomnienia mają formę dziennika, a każdy dzień jest opisywany przez autorkę według określonego schematu (w różnej kolejności) - wiadomości z kraju, wiadomości zza granicy, informacje dotyczące życia prywatnego. Po zamknięciu getta warszawskiego, w połowie listopada 1940 roku, w celu podreperowania budżetu (jak sama wspomina), Wyleżyńska rozpoczyna pracę polegającą na skupowaniu w getcie futer i sprzedawaniu ich z zyskiem po "stronie aryjskiej”. Z lektury jej dziennika wynika, iż pracę zorganizowała w ten sposób, że kontaktowała się telefonicznie z kimś z getta - pośrednikiem - który „organizował" futra oraz ich transport poza mur. Aurelia Wyleżyńska była więc "szmuglerką zorganizowaną"7 $\mathrm{W}$ „przedsiębiorstwie" zwanym gettem ${ }^{8}$. In-

\footnotetext{
6 A. Wyleżyńska, Notatki pamiętnikarskie, Archiwum Akt Nowych (AAN) „Dzienniki, Kroniki, Pamiętniki", sygn. 703/1. W tym i każdym kolejnym cytacie zapis odpowiada zapisowi autorskiemu.

7 Stosuję w tym miejscu rozróżnienie typów szmuglu zaproponowane przez Barbarę Engelking na indywidualny i zorganizowany [zob. B. Engelking, J. Leociak, Getto Warszawskie. Przewodnik po nieistniejącym mieście, Warszawa 2013, s. 481-496].

8 Sławomir Buryła zwraca uwagę na to, że okupacyjne zarządzenia dotyczące utworzenia gett na ziemiach okupowanych przez III Rzeszę można czytać również jako „podwaliny pod olbrzymie przedsiębiorstwo, które współtworzyli tak oprawcy, jak i mieszkańcy terenów podbitych" [S. Buryła Tematy (nie)opisane, Kraków 2013, s. 144].
} 
formacja o futrach i „niefunkcjonujących telefonach" pojawia się w jej pamiętniku wielokrotnie, zawsze jednak w kontekście "służbowym”. Wyleżyńska nie kwestionuje samego usankcjonowanego murem podziału, braku sprawiedliwości społecznej dopatruje się jednak w czynnikach dezorganizujących jej pracę. Autorka Notatek pamiętnikarskich nie zatrzymuje się nawet na chwilę nad kwestią etyczną wykonywanej przez siebie pracy. Utworzenie zamkniętej dzielnicy żydowskiej w Warszawie przyjmuje raczej jako nową możliwość ekonomiczną, a każde kolejne zarządzenie okupacyjne (na przykład zakaz posiadania futer przez osoby zmuszone zamieszkiwać getto ${ }^{9}$ ) jako źródło potencjalnego zarobku ${ }^{10}$.

Notatki pamiętnikarskie pisane były z intencją wydania po zakończeniu wojny. W pamiętniku pojawia się informacja o tym, że autorka dzieli się z przyjaciółmi pewnymi fragmentami swoich zapisków. Można więc uznać, że stosuje ona zasadę dotyczącą zapisywania rzeczy ważnych oraz - przynajmniej częściowej - autocenzury ${ }^{11}$. Aurelia Wyleżyńska zginęła w Warszawie $\mathrm{w}$ trakcie powstania $\mathrm{w}$ roku 1944, a jej pamiętnik nie doczekał się wydania W całości ${ }^{12}$.

Jedną z bardziej interesujących kwestii, pojawiających się $\mathrm{w}$ jej wspomnieniach, był zmieniający się $\mathrm{z}$ czasem stosunek autorki do ludności żydowskiej (zresztą cały pamiętnik stanowi wartościowy materiał badawczy). Można powiedzieć, że aż do momentu wybuchu powstania w getcie warszawskim Wyleżyńska nie wykazywała żadnej empatii wobec Żydów w związku z odbieraniem kolejnych praw. Dokonywane podziały i różne prawa dla poszczególnych grup (mimo iż wprowadzone przez rząd okupacyjny) w obrębie jednego społeczeństwa traktuje jako nieproblematyczne. Po wybuchu powstania w 1943 roku jej postawa uległa zmianie do tego stopnia, że zmodyfikowany został nawet sposób zapisu słowa „Żyd” - z małej litery przed powstaniem na wielką literę po jego wybuchu. Zmianę nastawienia można więc ujrzeć w samym zapisie. Próbując uchwycić kluczowe dla

9 Pod koniec grudnia 1941 roku komisarz Auerswald wydaje zarządzenie dotyczące konieczności oddania wszystkich futer. Za niezastosowanie się do zarządzenia groziły kary.

10 Sławomir Buryła nazywa to „Nowym Eldoradem” [por. S. Buryła, Tematy (nie)opisane].

11 Za wspólny namysł nad kwestią „prywatności” w praktykach diarystycznych dziękuję członkiniom zespołu Archiwum Kobiet IBL PAN.

12 Fragmenty pamiętnika zostały edytowane przez Jana Grabowskiego i ukazały się w 10 numerze rocznika "Zagłada Żydów. Studia i materiały" [zob. J. Grabowski, Biedni Polacy patrza na warszawskich Żydów i na getto warszawskie, "Zagłada Żydów. Studia i materiały" 2014, nr 10, t. 2, s. 527-557]. Tom ukazał się w grudniu, niewiele po tym, kiedy rozpoczęłam swoje badania w Archiwum Akt Nowych, gdzie znalazłam Notatki pamiętnikarskie w maszynopisie. Jan Grabowski wskazuje Bibliotekę Narodową w Warszawie jako miejsce przechowywania rękopisu. 
mojej analizy momenty, koncentrowałam się na występowaniu przekształceń semantycznych, przede wszystkim porównań, w tekście wspomnień Wyleżyńskiej. Porównania służą określeniu pewnych zjawisk za pomocą innych oraz „pozwalają wydobyć nowe odcienie znaczeniowe ze słów, pozwalają odnieść to, co nie znane, do tego, co znane, pozwalają abstrakcję sprowadzić do konkretu, rzecz niewyobrażalną - do wyobrażalnej"13.

W cytacie przytoczonym powyżej Aurelia Wyleżyńska używa konstrukcji bohatera zbiorowego, gdzie "my" odnosi się do nieżydowskiej społeczności ziem przyłączonych do III Rzeszy, "oni” są wprost przez autorkę nazwani Żydami. Zastosowanie przez nią w tym miejscu porównania ma na celu przybliżenie losu nieżydowskich mieszkańców ziem przyłączonych do Rzeszy z sytuacją, w jakiej znaleźli się Żydzi w ogóle. Nie jest więc przypadkiem, że desygnatem staje się właśnie w tym kontekście ów „los żydowski”, jako synonim bycia całkowicie pozbawionym praw. Cała figura stylistyczna zawiera w sobie jednak pewną ambiwalencję. Autorka posiada wiedzę o sytuacji, w jakiej znalazła się ludność żydowska, lecz jej nie problematyzuje. Owa sytuacja symbolicznie staje się synonimem odbierania „swobód obywatelskich", lecz służy jedynie zobrazowaniu pozycji, w jakiej znalazła się grupa, z którą ona sama się identyfikuje. Izolacja i odbieranie praw Żydom nie dziwi jej - dziwi ją (nad czym ubolewa) stawianie w "tej samej" sytuacji Polaków.

W tym kontekście warto podkreślić, że na terenach włączonych do III Rzeszy Polacy nigdy nie byli prześladowani, izolowani, poniżani, ograbiani i represjonowani w ten sam sposób, co Żydzi. W monografii "Żydów łamiacych prawo należy karać śmiercią!". "Przestępczość” Żydów w Warszawie 1939-1942 Barbara Engelking i Jan Grabowski wyróżniają kilka „sfer kryminalizacyjnych", wpływających na życie codzienne ludności żydowskiej w tym czasie: sfera symboliczna, której to zarządzenia „nie godziły co prawda w podstawy bytu polskich Żydów, lecz miały ich upokorzyć i w sposób widoczny zepchnąć na samo dno drabiny społecznej"14, ograniczenie prawa własności i ograniczenie prawa pobytu. W żadnej z tych sfer sytuacja Polaków nie była analogiczna z sytuacją ludności żydowskiej. Funkcją zastosowanego przez Wyleżyńską porównania jest więc hiperbolizacja polskiego cierpienia.

13 M. Głowiński, A. Okopień-Sławińska, J. Sławiński, Zarys teorii literatury, Warszawa 1967, s. 111.

14 B. Engelking, J. Grabowski, „Żydów łamiących prawo należy karać śmiercia!”. "Przestępczość” Żydów w Warszawie 1939-1942, Warszawa 2010, s. 16. 
Podobny zabieg stylistyczny widoczny jest w poniższym fragmencie:

Po roku wydano rozkaz, aby wszyscy Żydzi zamieszkali w utworzonym ghetcie, z którego mało kto uszedł z życiem; ghetto zostało w końcu zbombardowane i spalone w czasie powstania żydowskiego a mieszkańcy wywiezieni do Treblinki.

Niemniej bestialsko szalały niemieckie zbiry i w dzielnicy aryjskiej. Ciągłe łapanki, aresztowania, rozstrzeliwania niewinnych na ulicach, więzienia, obozy, czyniły życie mieszkańców Warszawy nie do zniesienia. To metodyczne tępienie polskiego narodu doprowadziło w 1944 roku do powstania ${ }^{15}$.

Tekst, z którego pochodzi powyższy cytat, jest wspomnieniem przysłanym na konkurs literacko-historyczny tygodnika "Stolica” pt. Warszawa moich wspomnień. Konkurs ogłoszony został na początku 1947 roku na łamach tygodnika ${ }^{16}$ i spotkał się ze znacznym odzewem. W skład jury konkursowego wchodziły i wchodzili przedstawiciele Ministerstwa Kultury, Archiwum Miejskiego, Związku Zawodowego Literatów oraz redakcji „Stolicy”. Przez kilka miesięcy kilkadziesiąt osób mieszkających w Polsce (choć nie tylko) przysyłało swoje wspomnienia na adres redakcji. Prace były anonimowe, oznaczone jedynie godłem, a w osobnej kopercie autorka czy autor zobowiązani byli przysłać swoje dokładne dane ${ }^{17}$. Ogłoszeniu konkursu przyświecała nie tylko chęć odbudowy (a właściwie stworzenia na nowo, zniszczonych w trakcie wojny, zbiorów archiwalnych), lecz przede wszystkim - udostępnienia przestrzeni do wypowiedzi tym osobom, które Warszawę pamiętają sprzed wojny. W odezwie konkursowej pisano: „Warto więc dziś jeszcze, póki żyją ci, co dzień wczorajszy pamiętają, pokusić się o to, aby obraz Warszawy możliwie wiernie odtworzyć i przyszłym pokoleniom należycie przekazać" ${ }^{\prime 18}$. Wbrew jednak oczekiwaniom pomysłodawców i pomysłodawczyń, większość prac konkursowych skupiała się na okresie i doświadczeniu wojennym oraz bazowała na prywatnych przeżyciach i wspomnieniach. Jedną $\mathrm{z}$ takich prac jest Spojrzenie wstecz Jadwigi Murzynowskiej. O autorce wiadomo jedynie tyle, że przed wojną mieszkała w Warszawie, wojnę przeżyła w Polsce, a po wyzwoleniu zamieszkała w Będzinie. W 1947 roku przysłała swoje wspomnienia na konkurs „Stolicy”. Praca liczy czternaście stron

\footnotetext{
15 J. Murzynowska, Spojrzenie wstecz, Archiwum Państwowe w Warszawie (APW), „Zbiór rękopisów", sygn. 249.

16 Warunki konkursu Warszawa moich wspomnień zostały ogłoszone w numerze 3 (12) „Stolicy” z 26 stycznia 1947 roku, s. 7.

17 Był to sposób anonimizacji prac przed oceną sądu konkursowego tak, by osoba oceniająca nie miała wglądu w personalia osoby, której pracę oceniała.

18 „Tygodnik Ilustrowany Stolica" 1947, nr 3, s. 7.
} 
maszynopisu i zawiera niewiele informacji dotyczących położenia, w jakim znalazła się ludność żydowska podczas wojny. Powyższy więc fragment jest jednym z trzech w całym wspomnieniu, gdzie pojawia się wzmianka o Żydach mieszkających w Warszawie.

W powyższym cytacie z jednej strony występuje zestawienie: rozkaz, getto, powstanie, Treblinka, a z drugiej strony - „metodyczne tępienie polskiego narodu", co prowadzi do kilku wniosków. Po pierwsze, Jadwiga Murzynowska, pisząc swoje wspomnienie już po wojnie, dokładnie wiedziała, co "stało się" z gettem warszawskim i większością jego mieszkańców (masowa eksterminacja Żydów jeszcze w czasie trwania wojny należała do tak zwanej „wiedzy ogólnej”). „Nie mniej bestialsko” oznaczałoby w tym wypadku, że skala przemocy poza murami getta była taka sama, bądź nawet większa (kwantyfikator „nie mniej”) niż przemoc, której dokonywano wewnątrz getta. Mamy tu więc do czynienia z aktem tworzenia „analogii bez analogii"19. Po drugie, w zestawieniu, a dokładnie w drugiej jego części, pojawia się sformułowanie „naród polski”. Po jednej stronie więc mamy getto, a po drugiej naród, co powoduje symboliczne wyłączenie z kategorii „narodu polskiego" osób zmuszonych zamieszkiwać getto ${ }^{20}$.

Kolejną próbę wyznaczenia symetrii doświadczenia osób zamieszkujących getto i przebywających poza jego granicami dostrzec można w innym fragmencie tego samego wspomnienia:

[O wiośnie 1943 roku] W dwa dni potem fruwały nad miastem pióra z podartych poduszek i pierzyn a ostra woń spalenizny wdzierała się wszędzie.

Płonęło Ghetto żydowskie. Waliły się domy i ulice tamtej, zamurowanej części Warszawy. A tysiące ludzi znajdujących się na dnie rozpaczy broniły już nie wolności, lecz tylko życia wydzieranego im okrutnie.

Przez długie letnie miesiące nie gasła krwawa łuna i nie cichły odgłosy walk.

- Ghetto płonie - mówiono z grozą.

- Poczekajcie, z nami zrobią to samo - Wróżyli pesymiści. Jak wykończą Żydów to się wezmą za Polaków ${ }^{21}$.

Symetrię doświadczeń w tymże fragmencie wyznacza zwrot "to samo". W tym samym cytacie pojawia się inny, interesujący fragment - autorka zaznacza, że to „pesymiści wróżyli”. Można odnieść wrażenie, że tylko nieliczni, ci źle nastawieni i pesymistycznie myślący powstrzymali resztę przed

\footnotetext{
19 Jest to kategoria stworzona przez Elżbietę Janicką [zob. E. Janicka, Pamięć przyswojona. Koncepcja polskiego doświadczenia zagłady Żydów jako traumy zbiorowej w świetle rewizji kategorii świadka, „Studia Litteraria et Historica” 2013/2014, nr 3/4, s. 151].

20 Do kwestii tej wrócę jeszcze w podsumowaniu.

${ }^{21}$ J. Murzynowska, Spojrzenie wstecz, dz. cyt.
} 
niesieniem ratunku. Dodatkowo, wyobrażenie całej tej sytuacji, ludzi patrzących i komentujących płonące podczas powstania getto, koresponduje z publikacją Jana Błońskiego ${ }^{22}$ Biedni Polacy patrzq na getto. Błoński zwrócił uwagę na próby nie tylko wyznaczania symetrii w doświadczeniu, ale i przeniesienia wagi z tragicznej śmierci mieszkanek i mieszkańców getta warszawskiego na mieszkańców i mieszkanki "tamtej strony”, którzy niejako zostali zmuszeni "to" oglądać. W pierwszej części cytatu wspomnienia znajduje się przecież bogaty opis tego, jak zza muru wyglądał ów zryw, co oznacza, że zarówno autorka, jak i „ogół społeczeństwa” miał świadomość tego, co działo się za murami getta.

\section{Ironia i alegoria}

Tyfus szalał, a tam za murami słupy i mury naszpikowane były afiszami głoszącymi o naszym brudzie, i nieodłącznych nam wszach, o tym, że my jesteśmy rozsadnikami epidemii, że jesteśmy zakałą świata i powinniśmy zginąć jak pasorzyty ${ }^{23}$ toczące ciało Europy. Że to my chcemy wytępić aryjskie ludy świata, że jesteśmy przyczyną wojny, że jesteśmy bogaczami siedzącymi na złocie, wyzyskiwaczami, którzy pragną opanować świat dla siebie. Jakież wnioski z tego. My przyczyna zła, mordercy świata musimy zginąć, a wraz z naszą śmiercią zapanuje wieczna zgoda przyjaźni narodów. Propaganda niemiecka nie żałowała trudu i póki się wysilała, póty się trudziła, aż wbiła w niektóre nieświadome umysły swoje hasła. Trudno było nie dać złapać się na lep obłudzie faszystowskiej, nie każdy miał tak jasny i trzeźwy umysł by nie wierzyć kłamstwom hitlerowskim. Nieuświadomiony tłum nie wgłębia się $\mathrm{w}$ istotę rzeczy, ale przyjmuje to, co zostało mu zręcznie podane przez sprytnego agitatora $^{24}$.

Stefania Szochur była aktorką, która przeżyła Zagładę w getcie warszawskim. Po powstaniu 1943 roku została wywieziona do Poniatowejej, skąd udało jej się uciec. Resztę wojny przeżyła w ukryciu. Po śmierci w 2004 roku, zgodnie z ostatnią wolą, jej prochy zostały rozsypane nad polami obozu zagłady w Treblince, a pamiętnik zdeponowano w Archiwum Żydowskiego Instytutu

\footnotetext{
22 J. Błoński, Biedni Polacy patrza na getto, Kraków 2008.

${ }^{23} \mathrm{~W}$ tym właśnie zapisie.

24 S. Szochur (Staszewska), Pamiętnik, AŻIH, sygn. 302/167.

25 Pod koniec 1942 roku obóz jeniecki dla więźniów radzieckich w Poniatowej został przekształcony w obóz pracy przymusowej. Przeniesiono tam częściowo zakłady Többensa z getta warszawskiego. Na początku listopada 1943 roku obóz został zlikwidowany, a osoby przebywające w nim rozstrzelano w akcji Erntefest (niem. dożynki). Zginęło wówczas ok. 18-20 tysięcy osób.
} 
Historycznego. Autorka spisywała swoje wspomnienia w trakcie okupacji hitlerowskiej.

Wzajemne wykluczanie się stereotypów nie stanowi powodu unieważnienia któregoś z nich. Powyższy fragment pamiętnika Stefanii Szochur znakomicie to oddaje. Co więcej, reguł dotyczących wyglądu, zachowania czy stanu posiadania jest tak wiele, że niemal niemożliwe wydaje się spełnienie wszystkich. Sprostanie obowiązującym normom w ramach jednego dyskursu może oznaczać przekroczenie ich w ramach innego. Autorka, mimo przebywania $\mathrm{w}$ getcie, znakomicie zdaje sobie sprawę z treści afiszy znajdujących się po drugiej stronie muru. Wśród wyliczanych przez nią epitetów pojawiają się właśnie te skrajne, które wzajemnie sobie przeczą, co wcale nie powoduje unieważnienia któregokolwiek $\mathrm{z}$ nich ${ }^{26}$. W opisie nie znajduje się co prawda jej własna ocena sytuacji, nie pisze ona również o emocjach, jakie w niej to budzi, jednak ironizuje: „My przyczyna zła, mordercy świata musimy zginąć, a wraz z naszą śmiercią zapanuje wieczna zgoda przyjaźni narodów". Ironię w tym miejscu odczytuję jako próbę zaznaczenia dystansu wobec sytuacji, w jakiej znalazła się Szochur, oraz chęć zobrazowania absurdalności treści afiszy.

O plakatach znajdujących się po drugiej stronie muru pisze również Aurelia Wyleżyńska:

Na ulicach i w tramwajach wiszą plakaty ilustrowane w sposób ohydny i głupi. Znów antyżydowska propaganda, Qui bono, pytam gdy oni za murami, gdy nawet echo telefoniczne zostało odebrane... [...]

Ktoś zwraca uwagę, napis u góry tłumaczy te wystąpienie niemieckie: Żyd oszust, to jedyny twój wróg. A jedyny! Prawie w każdym wozie afisz jest podarty lub rozdarty, czasem prawie zerwany. Publiczność polska dziwnie odporna, nie solidaryzuje się z tym serdecznym oświadczeniem, albo nie każdy zdoła je uchwycić; - jedyny wróg, więc Niemcy przyjaciele ${ }^{27}$.

Na początku Aurelia Wyleżyńska wprowadza informację o antysemickich plakatach rozwieszonych w mieście. Użycie przez nią sformułowania „znów antyżydowska propaganda" daje pewność, że podobny afisz wywieszany jest nie po raz pierwszy. Autorka wyraża zdziwienie bezsensownością umieszczania takich plakatów. Problemem nie jest jednak ich antysemicka treść zadziwiający wydaje się sam fakt pojawienia się tych ogłoszeń w sytuacji, gdy ludność żydowska zamknięta jest za murami.

26 Por. Z. Bauman, Nowoczesność i Zagłada, przeł. T. Kunz, Kraków 2009. s. 105.

27 A. Wyleżyńska, Notatki pamiętnikarskie, AAN „Dzienniki, Kroniki, Pamiętniki”, sygn. 703/1. 
W całości wspomnień Wyleżyńskiej uderza to, że mimo iż w dużej mierze odnosi się ona - nawet bezpośrednio - do sytuacji rozgrywających się $\mathrm{w}$ getcie, to ani razu nie neguje samej idei segregacji, czy - w tym przypadku - antysemickiej wymowy plakatów. Interpretacja Wyleżyńskiej skupia się na oburzeniu bezsensownością wywieszenia ich, skoro w Warszawie funkcjonuje już getto. Jej zdaniem więc opisany w afiszu problem po prostu nie istnieje. Analizy treści plakatu dokonuje - można powiedzieć - „ponad głowami" tych, do których się ona odnosi. Odczytuję to jako sygnał o symbolicznym odebraniu podmiotowości całej grupie, której dotyczy plakat. „Żyd oszust, jedyny twój wróg" dla autorki jest równoznaczne ze stwierdzeniem: "Niemcy przyjaciele". Słowo "Żyd" nie przestało być alegorią oszusta. Wydaje się, że gdyby z afisza wykreślono słowo ,jedyny", być może taki plakat nie zwróciłby jej uwagi, gdyż nie przedstawiałby "treści budzących kontrowersje”, czy też takich, które nie odwoływałyby się do „utrwalonych wyobrażeń społecznych" 28 .

Stefania Szochur zdaje sobie sprawę z polskiego antysemityzmu. Dla Aurelii Wyleżyńskiej jest on faktem instytucjonalnie wprowadzonym przez władze okupacyjne. Neguje ona nie sam akt segregacji i treść plakatów, tylko - jak to określiła - sens afisza: „Niemcy przyjaciele”. Wyleżyńska w ani jednym miejscu nie zaprzecza temu, jakoby Żydzi byli „oszustami” $\mathrm{i}$ „wrogami” - wprost przeciwnie - z wypowiedzi wynika, że wrogami są, ale nie jedynymi. Nie utożsamia jednak takiej postawy z antysemityzmem. Dla niej getto to zamknięta część miasta, z którą "robi interesy”. Zdaniem Sidonie Smith i Julii Watson to właśnie zestawianie narracji autobiograficznych kobiet o różnych doświadczeniach pozwala dostrzec $\mathrm{w}$ nich pewne pęknięcia ${ }^{29}$, które otwierają kolejne pola analizy. W powyższym przykładzie właśnie to, po której stronie muru getta się znalazły, determinuje całe późniejsze doświadczenie tego okresu, oraz każdą $\mathrm{z}$ nich lokuje $\mathrm{w}$ innym miejscu hierarchii społecznej.

Inny przykład zastosowania ironii odnalazłam we wspomnieniu Melanii Wasermanówny:

Na środku ulicy Żelaznej, tuż obok cukierni Sommera, stanął dziwny twór, owoc genialnej niemieckiej pomysłowości, która nie znała co to przeszkody: cztery bramy ustawione prostopadle względem siebie, zamknięte tworzyły że-

\footnotetext{
28 M. Głowiński, A. Okopień-Sławińska, J. Sławiński, Zarys teorii literatury, s. 125.

29 Sidonie Smith i Julia Watson zwracały uwagę na różnicę na osi innej niż płeć (klasa, „rasa”, etniczność) [S. Smith i J. Watson, Wprowadzenie: koncepcje podmiotowości w kobiecych praktykach autobiograficznych, przeł. A. Grzemska, M. Wesołowska, w: Teorie wywrotowe. Antologia przekładów, red. A. Gajewska, Poznań 2012, s. 66-72].
} 
lazną klatkę jak w menażerii. Otwierały się tylko parami, otwierając przelotu tramwajom i pieszym wzdłuż ulicy Chłodnej - jezdnia była cała aryjska - lub też gdy pozostała para wierzei była zamknięta - przepuszczały przez ulicę Żelazną żydowskie riksze. Innych środków lokomocji w tej stronie żydowskiej dzielnicy nie było.

Przez cały dzień otwierało się i zamykało to żelazne pudełko na rogu Chłodnej i Żelaznej. $Z$ okien przejeżdżających tramwajów widziało się opalone twarze o wyrazie czasem zaciekawienia, czasem obojętności, niekiedy - zawstydzenia. Ludzie na pozór wolni, mijali zamkniętych ludzi ghetta. W tym jednym punkcie miasta jawnie stykały się rozgraniczone sztucznie dwa światy.

Żandarm stojący $\mathrm{w}$ żelaznym pudełku bramy pod mostem zadzierał głowę w górę i groził każdemu, kto choć na chwilę zatrzyma się na platformie mostu. Most nie jest do stania, most jest do przechodzenia, i to prędko, los, marsch! Nic nie pomagało: nawet $\mathrm{w}$ ciągu tej jednej chwili, króciutkiej jak zaczerpnięcie oddechu, można było zachwycić oko migawkowym widokiem pejzażu, za którym serce tęskniło, namiętnie i bezsensownie: Plac Teatralny, wieża ratuszowa błękitniejąca w dali, mały balkonik na jej szczycie, tarcza zegara. Ziemia obiecana, raj utracony, miasto ukochane, do utraty tchu!

Potem już było łatwiej, z tym widokiem pod powieką, schodzić w czarną czeluść Żelaznej, gdzie po dawnemu marły dzieci pod progami sklepów i ulicą wlokły się szkielety w łachmanach, niemające już siły by żebrać ${ }^{30}$.

Melania Wasermanówna w 1947 roku wzięła udział w przywoływanym już konkursie literacko-historycznym tygodnika "Stolica” pod hasłem Warszawa moich wspomnień. Jej praca Ulica Chłodna poświęcona jest w całości historii tytułowej ulicy. Wasermanówna zaczyna snuć opowieść niemalże w przeddzień wybuchu wojny, a wspomnienie kończy opisem ulicy po Wielkiej Akcji. W języku jej wspomnień pojawiają się liczne tropy: porównania, personifikacje i właśnie ironia.

Skrzyżowanie ulic Chłodnej i Żelaznej w Warszawie to miejsce, w którym możliwe było przejście $\mathrm{z}$ dużego do małego getta (bądź odwrotnie). Jako że ulica Chłodna, a właściwie jej jezdnia, wyłączona została z zamkniętej dzielnicy żydowskiej, skrzyżowania pilnie strzeżono. Konstrukcja bramy (dwóch par wrót ustawionych na skrzyżowaniu), która zatrzymywała ludzi i pojazdy przy samej ulicy - niemal jak w kadrze - wystawiała osoby stojące przy ogrodzeniu na widok tych przechodzących czy przejeżdżających tramwajem. Warto zaznaczyć, że brama obsługiwana była w ten sposób, by zapewnić płynną komunikację „aryjskiej” części miasta, a nie gettu. Wasermanówna odnosi się do wyrazu twarzy ludzi zaglądających do getta: „Z okien przejeżdżających tramwajów widziało się opalone twarze o wyrazie czasem

30 M. Wasermanówna, Ulica Chłodna, APW „Zbiór rękopisów”, sygn. 439. 
zaciekawienia, czasem obojętności, niekiedy - zawstydzenia". W odróżnieniu od postawy Aurelii Wyleżyńskiej jej opisy są pełne empatii, kwestionuje ona samą ideę wydzielenia zamkniętej dzielnicy. Mur to dla niej rana na ciele miasta, oczekuje - w imieniu Chłodnej - jego zburzenia. Wasermanówna, przybliżając wygląd bramy, używa ironicznego określenia: „owoc genialnej niemieckiej pomysłowości". Podobnie jak w przypadku wspomnień Stefanii Szochur, autorka Ulicy Chłodnej w subtelny sposób drwi z opisywanej przez siebie konstrukcji. Ironia dokładnie obrazuje jej nastawienie do bramy, a pozytywne fragmenty opisu kładki wiążą się tylko z możliwością wyglądania poza mury getta.

Opisywaną przez Melanię Waserman kładkę zaprojektował Mosze Ring, a stanęła ona nad ulicą Chłodną dokładnie 26 stycznia 1942 roku. Służyła aż do Wielkiej Akcji, zanim małe getto zlikwidowano, po czym została rozebrana. Wybudowano ją, by usprawnić łączność nie tyle między dużym a małym gettem, lecz by zachować jeden z ważniejszych wówczas korytarzy komunikacyjnych Warszawy. Sfinansowana przez Wydział Techniczny Judenratu kładka nad ulicą Chłodną dzięki wysokości, na jakiej została ustawiona, stwarzała możliwość wyglądania daleko poza mury, co było próbą oderwania się od koszmarnej rzeczywistości, pełnej śmierci, bólu i głodu. Należy pamiętać, że na kładkę nie wszyscy mogli wejść. By przejść z jednej części getta do drugiej należało pokonać około pięćdziesięciu stopni w każdą stronę. Dla osób, których codzienność definiował brak jedzenia, niejednokrotnie było to niemożliwe. Kładka więc, mimo iż była mostem łączącym getto z gettem, stanowiła też granicę niemożliwą do przekroczenia. Kolejną granicę w getcie i kolejny symbol poniżenia ${ }^{31}$.

\section{Wnioski}

W momencie rozpoczęcia drugiej wojny światowej, w obliczu instytucjonalnej izolacji Żydów od reszty społeczeństwa, zmianie uległy wszelkie normy (społeczne, prawne, etyczne itd.) i z izolacji symbolicznej przekształcone zostały w formalną izolację przestrzenną. Jak trafnie zauważyła Judith Butler: „[p]odmioty konstytuowane są na bazie norm, które w procesie re-

31 Elżbieta Janicka nazywa kładkę „,bramą triumfalną polskiej opowieści”. I istotnie - patrząc na kładkę z perspektywy ulicy Chłodnej widziało się budowlę kształtem przypominającą łuk triumfalny, którym szły osoby stojące nieporównywalnie niżej w hierarchii społecznej. Więcej o samej kładce zob.: E. Janicka, T. Żukowski, Przemoc filosemicka? Nowe polskie narracje o Żydach po roku 2000, Warszawa 2016. 
iteracji wytwarzają i przesuwają warunki uznania podmiotów" ${ }^{32}$. Usunięcie Żydów poza nawias życia społecznego traktować więc możemy jako efekt przesunięcia owego warunku uznania $\mathrm{w}$ obliczu wprowadzonych (mimo że przez okupanta) norm - $w$ tym wypadku prawnych. Za wart podkreślenia uważam fakt, że miejscem utrwalania i reprodukcji stosunków dominacji nie jest "uniwersum domowe", lecz lokuje się ono na poziomie instytucjonalnym ${ }^{33}$. Biorąc za punkt wyjścia baumanowskie stwierdzenie, że naród "traktuje świadomość jako jedną ze swoich cech konstytutywnych" ${ }^{34}$, można zadać sobie pytanie, czy II wojna światowa, będąca zagrożeniem dla "narodu”, nie prowadziła do wzrostu "tego czegoś”, co Bauman nazwał „świadomością", mając na myśli świadomość narodową. Wzrost świadomości (rozumianej w kategoriach świadomości narodowej właśnie) w tym przypadku może prowadzić (i zdaniem Butler czy Baumana prowadzi) do nasilenia postaw nacjonalistycznych, jako reakcji na poczucie zagrożenia związanego z wojną. Wykluczenie części społeczeństwa poza nawias życia społecznego w związku $\mathrm{z}$ wprowadzeniem (w tym przypadku) w Warszawie getta nie było jednak identyfikowane jako zagrożenie dla "polskości”, nie było odbierane przeciw interesowi narodowemu - nie wymagało więc interwencji. Stosunki dominacji oraz pozycja w hierarchii społecznej okazały się wystarczające, by przemoc symboliczna po przesunięciu norm (po rozpoczęciu wojny) nabrała materialnego wymiaru.

Jak starałam się wykazać w powyższym artykule, materialny wymiar przemocy symbolicznej można odczytać literalnie, analizując język wspomnień. Wskazane przeze mnie przekształcenia semantyczne ujawniają napięcia symboliczne oraz świadomość (bądź nieświadomość) autorek w tym zakresie. Język wspomnień, bez znaczenia, czy były one pisane podczas wojny, czy już po jej zakończeniu, obrazuje nie tylko pozycję zajmowaną w hierarchii społecznej, lecz również indywidualne praktyki autorek. We wskazanych przeze mnie fragmentach dotyczących wnętrza żydowskiej dzielnicy zamkniętej i z niej pochodzących, postawą przyjętą wobec przemocy okazała ironia i związany $\mathrm{z}$ nią dystans. Autorki wspomnień były świadome swojej pozycji oraz kwestionowały ją. Zupełnie odmienne doświadczenia i postawy wykazywały autorki wspomnień spoza getta warszawskiego. Oczywiście zdaję sobie sprawę z tego, że wspomnienia te, napisane już po wojnie, dodatkowo będące pracami konkursowymi, należą do innego rodzaju

32 J. Butler, Ramy wojny. Kiedy życie godne jest optakiwania?, przeł. A. Czarnacka, Warszawa 2011, s. 44.

33 P. Bourdieu, Męska dominacja, s. 11.

34 Z. Bauman, Kultura jako praxis, przeł. J. Konieczny, Warszawa 2012, s. 57. 
narracji niż chociażby Notatki pamiętnikarskie, nie mniej jednak nie ma to wpływu na refleksję dotyczącą samego ich języka, będącą podstawą niniejszego artykułu.

\section{Bibliografia}

Bachmann-Medick Doris, Cultural turns. Nowe kierunki w naukach o kulturze, przeł. K. Krzemieniowa, Warszawa: Oficyna Naukowa, 2012.

Bauman Zygmunt, Nowoczesność i Zagłada, przeł. T. Kunz, Kraków: Wydawnictwo Literackie, 2009.

Bauman Zygmunt, Kultura jako praxis, przeł. J. Konieczny, Warszawa: Wydawnictwo Naukowe PWN, 2012.

Błoński Jan, Biedni Polacy patrza na getto, Kraków: Wydawnictwo Literackie, 2008.

Bourdieu Pierre, Męska dominacja, przeł. L. Kopciewicz, Warszawa: Oficyna Naukowa, 2004.

Bourdieu Pierre, Medytacje pascaliańskie, przeł. K. Wakar, Warszawa: Oficyna Naukowa, 2006.

Buryła Sławomir, Tematy (nie)opisane, Kraków: Universitas, 2013.

Butler Judith, Ramy wojny. Kiedy życie godne jest opłakiwania?, przeł. A. Czarnacka, Warszawa: Instytut Wydawniczy Książka i Prasa, 2011.

Ciało i tekst. Feminizm w literaturoznawstwie - antologia szkiców, t. 2, red. A. Nasiłowska, Warszawa: IBL PAN, 2001.

Engelking Barbara, Grabowski Jan, „Żydów łamiacych prawo należy karać śmiercią!”. „Przestępczość" Żydów w Warszawie 1939-1942, Warszawa: Stowarzyszenie Centrum Badań nad Zagładą Żydów, 2010.

Engelking Barbara, Leociak Jacek, Getto Warszawskie. Przewodnik po nieistniejacym mieście, Warszawa: Stowarzyszenie Centrum Badań nad Zagładą Żydów, 2013.

Głowiński Michał, Okopień-Sławińska Aleksandra, Sławiński Janusz, Zarys teorii literatury, Warszawa: Państwowe Zakłady Wydawnictw Szkolnych, 1967.

Grabowski Jan, Biedni Polacy patrza na warszawskich Żydów i na getto warszawskie, „Zagłada Żydów. Studia i materiały" 2014, nr 10, t. 2, s. 527-557.

Gross Jan Tomasz, Upiorna dekada, Kraków: Universitas, 2001.

Janicka Elżbieta, Żukowski Tomasz, Przemoc filosemicka? Nowe polskie narracje o Żydach po roku 2000, Warszawa: Wydawnictwo IBL PAN, 2016.

Janicka Elżbieta, Pamięć przyswojona. Koncepcja polskiego doświadczenia zagłady Żydów jako traumy zbiorowej w świetle rewizji kategorii świadka, „Studia Litteraria et Historica" 2014/2015, nr 3/4, s. 134-226.

Kłosińska Krystyna, Feministyczna krytyka literacka, Katowice: Wydawnictwo Uniwersytetu Śląskiego, 2010.

Leociak Jacek, Tekst wobec Zagłady. O relacjach $z$ getta warszawskiego, Toruń: Wydawnictwo UMK, 2016.

Woman and the Holocaust: New perspectives and challenges, red. A. Petö, L. Hecht, K. Krasuska, Warszawa: Wydawnictwo IBL PAN, 2015. 
Smith Sidonie, Watson Julia, Wprowadzenie: koncepcje podmiotowości w kobiecych praktykach autobiograficznych, przeł. A. Grzemska, M. Wesołowska, w: Teorie wywrotowe. Antologia przekładów, red. A. Gajewska, Poznań: Wydawnictwo Poznańskie, 2012.

\section{Archiwalia}

Archiwum Żydowskiego Instytutu Historycznego (AŻIH), sygn. 302/167, Stefania Szochur (Staszewska), Pamiętnik.

Archiwum Akt Nowych (AAN), „Dzienniki, Kroniki, Pamiętniki” sygn. 703/1, Aurelia Wyleżyńska, Notatki pamiętnikarskie.

Archiwum Państwowe w Warszawie (APW), „Zbiór rękopisów”, sygn. 249, Jadwiga Murzynowska, Spojrzenie wstecz.

\section{Symbolism of the Wall: \\ The Functions of Semantic Transformations in the Warsaw Ghetto Memoirs}

\section{Summary}

Within the literary theory the category of comparison is used to describe a given phenomenon by referring it to another. It does not explain it in detail but builds on the general knowledge of one event by collating it with the other. Therefore, the main function of comparison is to create a non-existing link between what is unknown and what is well known. This stylistic device enables the author to describe one event through another, making the first one comprehensible. The author explore the process of development and fortification of the symbolic border between the "Aryan side" and the Warsaw Ghetto, which finds its linguistic expression in the style of wartime women memoires. Besides being a material and architectural border, delineated in the middle of the city, the Warsaw Ghetto wall indisputably constituted a figurative boundary. Constructed with the use of institutionalized violence, this particular barrier was symbolically strengthened by the deeply rooted dominance of the non-Jewish inhabitants of the city.

Keywords: Warsaw Ghetto, Ghetto wall, memoires, symbolic violence, antiSemitism 